PRACE NAUKOWE UNIWERSYTETU EKONOMICZNEGO WE WROCLAWIU

\title{
Maciej Filus
}

Uniwersytet Ekonomiczny we Wrocławiu

e-mail: mstf@poczta.onet.pl

\section{WPLYW OTWIERANIA GOSPODARKI NA LOKALNY RYNEK ZASOBÓW \\ THE IMPACT OF OPENING OF THE ECONOMY ON THE LOCAL RESOURCES MARKET}

DOI: $10.15611 /$ pn.2017.477.07

JEL Classification: E, F

Streszczenie: Artykuł jest próbą odpowiedzi na pytanie, jaki wpływ na lokalny rynek zasobów może mieć otwarcie gospodarki na konkurencję międzynarodową. Pierwsza część poświęcona jest szukaniu analogii między swobodnym przepływem zasobów a znanym z nauk przyrodniczych modelem destylacji Rayleigha. Analiza obu procesów i występujących między nimi analogii pokazuje, że przepływy finansowe oraz migracja, czyli zachowania ekonomiczne zarówno jednostek, jak i całych społeczności są bardzo zbliżone do mechanizmów występujących w przyrodzie podczas procesu parowania. Następnie na podstawie hipotezy Balassy-Samuelsona podjęto próbę opisania długookresowych konsekwencji otwarcia gospodarki kraju na konkurencję międzynarodową dla społeczności lokalnej. Szczególną uwagę zwrócono na wpływ, jaki na lokalny rynek pracy i finansów mają procesy migracji zarobkowej oraz zmiany struktury przemysłowej kraju.

Słowa kluczowe: destylacja zasobów, hipoteza Balassy-Samuelsona, lokalny rynek pracy.

Summary: The article attempts to explain the impact, the opening processes of a national economy has on local resources market. It is done through the analogy to free flow of resources and Rayleigh distillation model, known from natural sciences. The analysis of both processes, together with their analogies, shows that financial flows and the migration i.e. economic behavior of individuals as well as the societies, are very close to the mechanisms that we can observe in the nature during evaporation. Next, using the Balassa-Samuelson analysis, the speed and strength of transition processes was described as well as the long run consequences for the local job and financial markets.

Keywords: resources distillation, Balassa-Samuelson effect, local job markets. 
Trzeba szerzyć prawdę- prawa ekonomii nie różnia się od praw mechaniki.

Te same prawa obowiąuja wszędzie.

Lawrence Summers, $1991^{*}$

\section{Wstęp}

Była 2. połowa XVIII w., gdy w Anglii zaczęły powstawać zręby teorii ekonomii klasycznej, która przez dekady, a właściwie do dziś stanowi podstawę do badań nad gospodarką regionalną, lokalną, a także nad wymianą międzynarodową. Wtedy też ukształtowały się i okrzepły podstawy kapitalizmu manufakturowego oraz swobodnie i nieskrępowanie rozkwitały idee liberalizmu gospodarczego [Smith 2007]. Wraz z kończącą się wówczas epoką wielkich odkryć geograficznych nastał czas wielkich wynalazków technicznych, nazywany rewolucją przemysłową ${ }^{1}$. Rozpoczął się proces mechanizacji produkcji, którego dynamika bardzo różniła się w poszczególnych krajach. Od tamtego czasu poszczególne kraje w różnych okresach prowadziły zróżnicowaną politykę gospodarczą. Raz bardziej liberalną, otwierając się na gospodarkę światową, a innym razem bardziej interwencjonistyczną, zamykając się przed gospodarkami innych państw, np. poprzez ustanawianie ceł i zamykanie granic [James 2010]. Jednak zawsze kraje mające przewagę konkurencyjną ${ }^{2}$ nad innymi, dzięki zaawansowanemu technologicznie i zmechanizowanemu przemysłowi, były bardziej liberalne gospodarczo i opowiadały się za otwieraniem rynków, zaś kraje rolnicze, w których raczkujący przemysł oparty był na przestarzałych i mało efektywnych technologiach, miały skłonności protekcjonistyczne i były bardziej skore do interwencjonizmu w celu ochrony i wsparcia rodzimego przemysłu. Takie zapadające „na górze” decyzje dotyczące polityki gospodarczej i handlowej zawsze miały niebagatelny wpływ na życie zwykłych ludzi oraz kształtowany przez nich lokalny rynek zasobów pracy i kapitału.

* Lawrence Summers - były główny doradca ekonomiczny Banku Światowego [Keegan 1992, s. 109].

${ }^{1}$ W zasadzie czas przełomu tych dwóch epok: epoki wielkich odkryć geograficznych i rewolucji technicznej, możemy porównać do zaistniałego w średniowieczu przejścia od rolnictwa ekstensywnego do intensywnego. W momencie gdy wypalono i wykarczowano ostatnie lasy na europejskich nizinach, wyczerpały się możliwości prostego zwiększania produkcji rolnej przez pozyskanie nowych terenów do uprawy. Wówczas jedynym sposobem na zwiększenie efektywności w rolnictwie było zastosowanie bardziej wydajnych technik uprawy. Współcześnie mamy do czynienia z analogiczną sytuacją, gdyż nadprodukcja prostych wyrobów przemysłowych wymusza tworzenie i rozwój nowych technologii na skalę nieznaną jeszcze w historii.

${ }^{2}$ Przewagę konkurencyjną mają kraje, które w długim okresie osiągają dodatni bilans handlowy, czyli wartość eksportu przewyższa wartość importu. 


\section{Zasoby}

W teorii ekonomii klasycznej [Bożyk, Misala, Puławski 2002] w zasadzie jedynymi czynnikami decydującymi o bogactwie danego państwa są jego nieprzenośne (lub w najlepszym wypadku trudno przenośne) zasoby, na które składają się ziemia, praca i kapitał [Landes 2008]. W takiej sytuacji międzynarodowej wymianie mogą podlegać w zasadzie tylko wytworzone w danym kraju towary. Współcześnie patrzymy na zasoby w nieco inny sposób niż pod koniec XVIII lub XIX wieku [Begg, Fischer, Dornbusch 2007]. Ziemia jest nadal najbardziej statycznym, stałym i nieprzenośnym (w kontekście wymiany międzynarodowej) zasobem, ale od jej jakości zależy, czy dany kraj będzie dla jego mieszkańców miejscem dogodnym do życia, czy też nie. Jeśli ziemia jest urodzajna, a dodatkowo bogata w łatwo dostępne kopaliny, to będzie cennym zasobem. Gorzej, gdy dany kraj leży na piaszczystych albo bagnistych ugorach i jest pozbawiony kopalin. W pierwszym przypadku „wszyscy” chcieliby nabyć taką ziemię lub ją zagarnąc siłą i na niej się osiedlić, zaś w drugim - niekoniecznie.

Praca to de facto ludzie. Bogactwo danej społeczności zależy od ich wykształcenia, pracowitości, przedsiębiorczości oraz innowacyjności. Nie bez znaczenia są też takie cechy, jak: uczciwość, solidność i poczucie tożsamości z lokalnym rynkiem i społecznością.

Kapitał to inaczej zamożność społeczeństwa wyrażona w postaci środków pieniężnych, środków trwałych i zasobów intelektualnych przynoszących zyski ich właścicielom. Są to nieruchomości, budowle infrastrukturalne, fabryki oraz zgromadzone indywidualnie przez mieszkańców oszczędności i aktywa, które dzięki nowym technologiom i globalnemu systemowi bankowemu można łatwo przenosić w poszukiwaniu większego zysku. Niemniej przenoszenie kapitału za granicę jest bardziej handlem tytułami własności niż fizycznym przenoszeniem zasobów. Pierwotnie kapitał był przywiązany do miejsca, a na jego wywóz (sprzedaż) za granicę trzeba było uzyskać specjalne pozwolenie od monarchy czy rządu. Mniej więcej od 2. poł. XX w. kapitał został pozbawiony domu i narodowości.

\section{Teoria destylacji zasobów}

W naukach przyrodniczych są dobrze znane i opisane zjawiska destylacji i ewapora$\mathrm{cji}^{3}$, których skutkiem jest rozdzielenie mieszaniny roztworu na składniki. Proces ten polega na odparowaniu, odprowadzeniu, a następnie skropleniu powstałych par [Jarociński, Jarosz 1980]. Gdy zamknięte naczynie wypełnione mieszaniną cieczy wraz z rozpuszczonymi w nich gazami i solami zostanie otwarte, natychmiast odparują z niego składniki najbardziej lotne [Hoefs 1973; Kroopnick, Craig 1972; Mook,

${ }^{3}$ Destylacja odnosi się do rozpuszczonych w roztworze gazów i cieczy, zaś ewaporacja do rozpuszczonych w roztworze soli. 
Bommerson, Staverman 1974]. Z czasem będą odparowywały substancje coraz cięższe i trudniej rozpuszczalne, a na samym końcu odparuje pogon ${ }^{4}$, powodując wytrącanie się rozpuszczonych $\mathrm{w}$ nim soli. W warunkach laboratoryjnych tempo tego procesu można regulować poprzez podniesienie lub obniżenie temperatury lub ciśnienia. Można też po prostu ponownie zamknąć naczynie i przerwać proces parowania $\mathrm{w}$ dowolnym momencie, pamiętając jednak o uprzednim schłodzeniu całego układu, w przeciwnym razie może dojść do eksplozji [Jędrysek 1990].

Jeżeli powyższy model odniesiemy do nauk społecznych, gdzie procesowi parowania i skraplania będzie odpowiadał swobodny przepływ zasobów, mieszaniną cieczy będzie społeczeństwo, ciśnieniem - otoczenie prawne i infrastrukturalne, a temperaturą - stosunki społeczne i relacje międzyludzkie, łatwo przewidzieć, jakie skutki przyniesie otwarcie rynku dla lokalnej gospodarki. Ponieważ kapitał jest najbardziej mobilnym z zasobów i najłatwiej go przemieszczać nie tylko między systemami bankowymi lub giełdowymi, ale także między krajami, natomiast współczesna technologia i Internet pozwalają inwestować go na drugim końcu świata w czasie quasi-rzeczywistym (zazwyczaj czas realizacji transakcji trwa od kilku sekund do kilku, kilkunastu godzin), to sytuacja społeczno-polityczna danego kraju (warunki temperatury i ciśnienia) będzie decydowała o tym, czy i kiedy kapitał „odparuje i odleci" lub pozostanie. Jeśli mamy do czynienia z gospodarką kraju o słabej infrastrukturze, ze źle rozwiniętą służbą zdrowia i edukacją oraz z niestabilnym, często zmieniającym się prawem, wysokimi podatkami, a dodatkowo zamieszkujące go społeczeństwo jest podzielone i targane ciągłymi konfliktami, wówczas kapitał najszybciej jak to możliwe odpłynie do rynków, gdzie warunki prawne i społeczne są stabilniejsze.

W 1998 roku Bank Światowy, MFW i rząd Japonii udzieliły Rosji pożyczki w wysokości 22,6 mld USD na podtrzymanie wartości rubla i odsunięcie w czasie nadchodzącego kryzysu. Według Josepha Stiglitza władze MFW i Banku Światowego liczyły, że pożyczka ta pozwoli ustabilizować sytuację i opóźnić dewaluację rubla przynajmniej o trzy miesiące. Jednak oligarchom powiązanym z Kremlem wystarczyły zaledwie godziny i dni, by wytransferować całą kwotę do banków cypryjskich i szwajcarskich, a po trzech tygodniach rząd Rosji jednostronnie ogłosił niewypłacalność i zdewaluował rubla. W styczniu 1999 roku wartość rubla spadła o ponad 45\% w stosunku do poziomu z lipca 1998 roku [Stiglitz 2004]. Był to niekwestionowany (i chyba już nie do pobicia) ,rekord świata” w transferze kapitału za granicę.

W konsekwencji rynek lokalny takiej gospodarki zostaje pozbawiony środków do finansowania inwestycji i rozwoju, czego skutkiem może być dalsze „odparowywanie" kolejnego zasobu, jakim jest praca, czyli migracja (emigracja) ludności.

Praca za sprawą pracowników, czyli ludzi, którzy są powiązani więzami rodzinnymi, tradycją, przyzwyczajeniami, a często po prostu obciążeni własną nierucho-

${ }^{4}$ Pogon - inaczej ciecz wyczerpana, czyli nieodparowana pozostałość. Ciecz skroplona bogatsza w składnik lotniejszy nazywana jest destylatem. 
mości, jest zasobem dużo bardziej stabilnym. Oczywiście istnieje pewna część pracowników - zwłaszcza młodych - na dorobku, bez rodziny i zobowiązań. Ten zasób pracy jest mobilny i może nie z taką szybkością jak kapitał, ale tak samo bez sentymentów przenosi się w dowolne miejsce, gdzie życie wydaje się lżejsze, a praca pewniejsza i lepiej płatna. Zgodnie z prawem Rayleigha ${ }^{5}$, w pierwszej kolejności będą emigrowali pracownicy „najłatwiej rozpuszczalni”, tzn. o największych zdolnościach adaptacyjnych, znający języki, wykształceni, mający dobry fach i obycie w świecie. Przy podejmowaniu decyzji o poszukiwaniu lepszych warunków pracy i płacy największym problemem, jak się wydaje, są względy kulturowe i mentalne oraz poziom wykształcenia i samoocena pracowników, zaś kluczową okazuje się kwestia znajomości języków obcych oraz otwartości na innych ludzi i inne kultury. Oczywiście istnieje pewna część pracowników, którzy nigdy nie opuszczą swojej lokalnej ojczyzny, i w kontekście teorii destylacji możemy o nich mówić jak o pierwszych wytrąconych ewaporatach, czyli o „soli tej ziemi”.

Ponieważ ziemia, tak jak i pozostałe nieruchomości, jest zasobem stabilnym w sensie mobilności, to otwarcie gospodarki nie będzie miało żadnego wpływu na kształtowanie się rynku lokalnego. Co najwyżej zmieni się sąsiad na mniej sympatycznego, ale taka sytuacja może się zdarzyć i zapewne wielokrotnie się zdarza również w gospodarce zamkniętej. Sprzedaż ziemi obcokrajowcom wywołuje wiele kontrowersji i emocji. Główną, zresztą uzasadnioną obawą jest kwestia wytransferowania zysków za granicę, co pozbawi rynek lokalny środków, które mogłyby zostać zainwestowane na miejscu i przyczynić się do bardziej dynamicznego rozwoju kraju. Jednak, jak pokazał przykład Rosji lat 90., w otwartej gospodarce nie tylko zyski, ale nawet kapitał może zostać wytransferowany, i to przez własnych obywateli. $\mathrm{Z}$ drugiej strony historia zna wiele przypadków, gdzie kolonistom z obcych krajów sprzedawano ziemię, a oni nie tylko rzetelnie ją uprawiali i inwestowali zyski na lokalnym rynku, ale przede wszystkim asymilowali się, nierzadko zmieniając wyznanie lub wchodząc w mieszane związki małżeńskie, stając się dobrymi obywatelami nowej ojczyzny.

Należy w tym miejscu zauważyć, że są na świecie kraje ze stabilnym systemem prawnym, niskimi podatkami, sprawną administracją, nowoczesną infrastrukturą oraz tolerancyjnym, życzliwym sobie społeczeństwem. W takich warunkach otwarcie gospodarki nie tylko powoduje „kondensację i skraplanie się” zasobów na rynkach lokalnych, ale nawet resublimację ${ }^{6}$ tych najbardziej „lotnych”, czyli kapitału. Oczywiście proces destylacji zasobów, jak każdy inny, można przerwać, chociażby przez zamknięcie granic, wprowadzenie ceł i zabranie paszportów, pamiętać jednak należy o grożącej możliwości wybuchu. W warunkach laboratoryjnych, a także

${ }^{5}$ Proces destylacji Rayleigha opisuje m.in. stopień zaawansowania reakcji w układzie otwartym, czyli pozwala obliczyć ilość materii, jaka została odprowadzona z układu. Dotychczas miał głównie zastosowanie do określania rozdziału faz oraz efektów izotopowych.

${ }^{6}$ Sublimacja - przemiana fazowa bezpośredniego przejścia ze stanu stałego w stan gazowy z pominięciem stanu ciekłego. Zjawisko odwrotne do sublimacji to resublimacja. 
przemysłowych proces destylacji możemy w pełni kontrolować dzięki zastosowaniu kolumn rektyfikacyjnych, gdzie poszczególne składniki ogrzewane są do konkretnej temperatury, a następnie skraplane i odprowadzane poza układ. W ekonomicznej rzeczywistości otwartego rynku rolę kontrolera migracji i transferów kapitału pełnią układy i umowy międzypaństwowe dwu- $\mathrm{i}$ wielostronne. Dodatkowo należy jeszcze wspomnieć, że procesy społeczno-ekonomiczne, które charakteryzują się zdecydowanie większą złożonością niż procesy zachodzące w przyrodzie, mogą być analizowane tylko w perspektywie długookresowej, gdyż w krótkich interwałach czasowych wyprowadzone wnioski mogą być niejednoznaczne i błędne.

Najlepszym dowodem prawdziwości wyżej opisanych teorii jest fakt stopniowego, ale ciągłego (długookresowego) procesu przenoszenia życia społecznego i gospodarczego ze wsi do miast, ze wschodniej Polski na Śląsk i do Wielkopolski, a z Europy Centralnej i Wschodniej do Zachodniej. Należy przy okazji zauważyć, że tempo tych procesów z dekady na dekadę przyspiesza, czego skutkiem są coraz poważniejsze problemy społeczno-polityczne na terenach zasiedlanych.

\section{Efekt Balassy-Samuelsona}

Efekt B-S pokazuje wpływ wydajności pracy na poziom płac w kraju w odniesieniu do wydajności pracy i poziomu płac za granicą w warunkach swobodnego przepływu zasobów. W sytuacji połączenia się kilku mniejszych krajów w jeden duży obszar gospodarczy, w którym zostaną zachowane dotychczasowe prawne, społeczne, i ekonomiczne warunki w każdym z nich, to automatycznie pierwotne rynki krajowe staną się rynkami regionalnymi, a w niektórych sytuacjach wręcz rynkami lokalnymi. W związku z tym przyjęcie definicji rynku krajowego, regionalnego i lokalnego zależy od wielkości skali i punktu odniesienia, bo jeśli np. jakiś kraj przystąpił do Unii Europejskiej, to automatycznie stał się jej regionem, a często tylko częścią jakiegoś regionu (np. Beneluxu, krajów bałtyckich czy Europy Wschodniej) i w tym kontekście stał się rynkiem lokalnym.

Do celów analizy Balassa i Samuelson, a wcześniej Penn [Samuelson 1994, s. 201-226] wydzielili z gospodarki sektor wytwarzający wyroby, które są przedmiotem eksportu (traded), oraz sektor wytwarzający produkty oraz świadczący usługi niebędące przedmiotem wymiany międzynarodowej (non traded), czyli np. usługi fryzjerskie albo sprzedaż piasku, którego koszt wydobycia powiększony o koszty transportu przewyższałby jego cenę w kraju ewentualnego importera ${ }^{7}$. Założyli oni, że zgodnie $\mathrm{z}$ prawem jednej ceny ${ }^{8}$ wyroby będące przedmiotem handlu międzynaro-

7 Obecnie uważa się, że nie ma już wyrobów non traded, czyli nieeksportowalnych. Szczególnie w strefach przygranicznych.

${ }^{8}$ Teoria ekonomiczna zakładająca istnienie jednakowej ceny produktu na całym rynku w przypadku braku ograniczeń handlowych oraz kosztów transportu i gdy rynek ten jest efektywny. W szczególności, jeśli istnieje handel zagraniczny, pojedynczym rynkiem jest reszta świata. 
dowego powinny w każdym kraju kosztować mniej więcej tyle samo (po skorygowaniu o koszty transportu), natomiast nakłady zasobów potrzebnych do wytworzenia tych produktów w poszczególnych krajach mogą się różnić. Mniejszy nakład pracy przy takiej samej cenie produktu powoduje, że wartość pracy wyrażona w poziomie płac będzie tym wyższa, im wydajniejsza $i$ bardziej efektywna jest gospodarka danego kraju, zaś ceny takich samych usług (non traded) w poszczególnych krajach będą się różniły i będą określone przez poziom płac wyznaczony przez sektor traded. Różnice te będą tym większe, im większe będą dysproporcje w wydajności pracy i efektywności wykorzystania zasobów. Zgodnie z hipotezą B-S otwarcie rynków zwiększy ekspozycję sektora traded na konkurencję zagraniczną. Aby jej sprostać, producenci będą musieli z jednej strony obniżać koszty produkcji, a z drugiej podnosić jakość swoich wyrobów, co powinno przełożyć się na wzrost ich efektywności, dzięki czemu możliwy będzie wzrost płac w sektorze traded. W sektorze non traded nie można w prosty sposób podnieść efektywności, ponieważ mechanik nie naprawi szybciej i lepiej samochodu, tak samo jak kucharz nie ugotuje szybciej równie smacznego obiadu, dlatego płace w tym sektorze nie zależą od wydajności, lecz od poziomu płac (efektywności pracy) w branżach eksportowych.

Skoro płace w krajach o efektywniejszych gospodarkach są wyższe niż w krajach o mniejszej efektywności, to zgodnie z hipotezą B-S, po otwarciu gospodarki (granic) należy spodziewać się przepływu pracowników do krajów o wyższej efektywności, co w pierwszym okresie może spowodować tam z jednej strony zahamowanie wzrostu płac, a nawet ich spadek, a z drugiej wzrost napięć społecznych pomiędzy pracownikami ,starymi” a nowo przybyłymi. Natomiast w krajach o niższej efektywności i niższych płacach można spodziewać się napływu inwestycji (kapitału zagranicznego) do pracochłonnych i mało efektywnych działów gospodarki (np. montowni). Jednak proces ten nie będzie miał większego wpływu na podniesienie poziomu wydajności pracy w krajach przyjmujących kapitał oraz nie będzie prowadził do szybkiego wzrostu płac.

Po otwarciu rynku powinien nastąpić przepływ zasobów do gospodarek, w których stosunki społeczno-ekonomiczne są stabilniejsze, a systemy bankowe bezpieczniejsze. Można się również spodziewać przepływu pracowników do krajów, gdzie są wyższe płace, czyli produktywność pracy mierzona wartością produkcji na zatrudnionego jest wyższa. W efekcie ww. procesów lokalni przedsiębiorcy działający w mniej efektywnej gospodarce mogą nie sprostać konkurencji, co zmusi ich do przestawienia swojej działalności z traded na usługowe (jako podwykonawców, np. wykonujących montaż) w stosunku do gospodarek krajów o wyższej efektywności. Dodatkowo w sytuacji odpływu pracowników będą zmuszeni podnieść płace, aby sprostać żądaniom lokalnego rynku pracy, co spowoduje wzrost cen świadczonych usług oraz spadek konkurencyjności, czego dalszą konsekwencją może być przeniesienie ich zleceń w inny region świata.

Opisane powyżej procesy i mechanizmy ekonomiczne dobrze obrazują polską rzeczywistość gospodarczą ostatniej dekady, gdzie likwidacji resztek przemysłu to- 
warzyszyła masowa migracja zarobkowa do krajów „starej Unii”. Niniejsze uwagi nie tylko nie wyczerpują omawianego tematu, ale ze względu na ograniczoność miejsca poruszają jedynie najważniejsze kwestie z nim związane. Autor uważa, że w zasadzie każdy wątek tego artykułu jest godny szerszego opracowania oraz głębszych rozważań i analiz.

\section{Wnioski}

1. Zasoby kapitałowe jako najbardziej mobilne zawsze pierwsze będą reagowały na zmianę bezpieczeństwa w otoczeniu społeczno-ekonomicznym. Jako najbardziej „lotne” zostaną „odparowane” i „odprowadzone” przy najmniejszym „podgrzaniu temperatury środowiska”, a ich „skraplanie i sublimacja” nastąpi w gospodarkach stabilniejszych i bezpieczniejszych.

2. Zasoby pracy, czyli pracobiorcy, stopniowo, ale stale będą przemieszczać się do krajów, w których są wyższe płace oraz lepsza opieka socjalna. Czas reakcji tego procesu jest znacznie wolniejszy niż w przypadku kapitału i zwykle wiąże się z dużym oporem ze strony przyjmującej, ponieważ napływ świeżej siły roboczej powoduje zakłócenia na zorganizowanym już rynku pracy, szczególnie gdy mamy do czynienia ze zjawiskiem o charakterze masowym. Proces migracji zarobkowej będzie tym intensywniejszy, im większe będą różnice poziomów wynagrodzeń.

3. Zgodnie z hipotezą Balassy-Samuelsona przedsiębiorstwa działające na mniej efektywnych rynkach lokalnych i niemogące sprostać konkurencji międzynarodowej będą stopniowo zamykane lub będą zmieniać profil na usługowy (np. montownie). Jednocześnie, przy zróżnicowaniu płac i ograniczonej przenośności pracy między krajami, kapitał (zagraniczny) będzie zainteresowany przenoszeniem pracochłonnych rodzajów działalności z krajów o wyższych zarobkach do krajów o niższym poziomie wynagrodzeń, a więc o niższej ogólnej wydajności pracy. Proces ten nie musi w znaczącym stopniu podnosić poziomu wydajności pracy w krajach przyjmujących kapitał i w konsekwencji prowadzić w nich do szybkiego wzrostu płac.

4. Szybszy wzrost wynagrodzenia pracy w gospodarkach o niższej wydajności mógłby być zapewniony poprzez pełną mobilność międzynarodową zasobu pracy, która zapewniłaby równiejsze szanse w konkurencji o podział korzyści między pracą i kapitałem, ponieważ z powodu większej mobilności i lepszego dostosowania do zmieniających się warunków rynkowych kapitał jest bardziej uprzywilejowanym zasobem niż praca.

5. W długim okresie zmiany na lokalnym rynku pracy (emigracja i związany z nią brak odpowiednio wykwalifikowanych pracowników) oraz wzrost wydajności w sektorze traded wymuszać będzie wzrost poziomu płac.

6. Otwieranie rynków gospodarek bardziej wydajnych (o wyższym poziomie płac) dla szerszego przepływu pracy z krajów o niższej wydajności powoduje w tych drugich wzrost płac bez uzasadniającego go wzrostu wydajności pracy. Czyli inaczej rzecz ujmując, wysoka wydajność pracy za granicą będzie wpływać na wzrost płac 
w kraju, przede wszystkim na skutek zmniejszania się liczby chętnych do podejmowania pracy za wynagrodzenie uzasadnione lokalną wydajnością pracy. W średniookresowej perspektywie może to wpłynąć na zmniejszenie atrakcyjności tych gospodarek dla kapitału poszukującego optymalizacji zysku, a opisane zjawiska już znajdują odzwierciedlenie na regionalnych rynkach pracy w Polsce.

\section{Literatura}

Begg D., Fischer S., Dornbusch R., 2007, Mikroekonomia, Polskie Wydawnictwa Ekonomiczne, Warszawa.

Bożyk P., Misala J., Puławski M., 2002, Międzynarodowe stosunki ekonomiczne, wyd. II, Polskie Wydawnictwa Ekonomiczne, Warszawa.

Hoefs J., 1973, Stable isotope geochemistry, Springer-Verlag, Berlin - Heidelberg - New York.

James H., 2010, Koniec globalizacji: czego nauczył nas wielki kryzys, Wydawnictwo Naukowe Scholar, Warszawa.

Jarociński J., Jarosz K., 1980, Gorzelnictwo i drożdżownictwo, Wydawnictwa Szkolne i Pedagogiczne, Warszawa.

Jędrysek M.O., 1990, Course-book of Isotope Geology, [w:] Jedrysek M.O. (ed.), Third School on Physics of Minerals, Part I - Isotopes, Wroclaw University and Committee on Mineralogical Sciences, Wrocław.

Keegan W., 1992, The Spectre of Capitalism: The Future of the World Economy After the Fall of Communism, Radius, London.

Klein N., 2008, Doktryna szoku. Jak współczesny kapitalizm wykorzystuje klęski żywiołowe i kryzysy społeczne, Muza SA, Warszawa.

Kroopnick P., Craig H., 1972, Atmospheric oxygen: isotopic composition and solubility fractionation, Science, vol. 175, no. 54.

Landes D.S., 2008, Bogactwo i nędza narodów, Muza SA, Warszawa

Mook W.G., Bommerson J.C., Staverman W.H., 1974, Carbon isotope fractionation between dissolved biocarbonate and gaseous carbon dioxide, Earth and Planetary Science Letters, no. 22.

Samuelson P.A., 1994, Facets of Balassa-Samuelson thirty years late, Review of International Economics, vol. 2, no. 3, s. 201-226.

Smith A., 2007, Badania nad naturą i przyczynami bogactwa narodów, cz. 1, Wydawnictwo Naukowe PWN, Warszawa.

Stiglitz J.E., 2004, Globalizacja, Wydawnictwo Naukowe PWN, Warszawa. 